\title{
Alcuin's Letters Sent from Francia to Anglo-Saxon and Frankish Women Religious
}

\author{
Jinty Nelson
}

In 2003, Barbara Yorke's Nunneries and the Anglo-Saxon Royal Houses offered radically new ways of thinking about religious women in the early medieval world. One was the realization that "kings could claim lordship over nunneries by virtue of their having been founded by members of the royal house." Another was that nunneries "were not so much passive places ... as playing a proactive role..." A third was that "an abbess had a position which paralleled that of a male equivalent in the church ... Headship of a royal monastery was ... a gendered role. It was one that only royal women could perform from the royal kin-group."1 Over the past fifteen years, abbesses have been the subject of much new thinking, not least from Barbara herself. In this paper, which I offer in her honour, and mindful of a venerable tradition of women's sending of munuscula, I begin by taking a comparative approach, juxtaposing some evidence from Continental Europe, especially Francia, to evidence from AngloSaxon England, in quite different genres of the same period. The genres in question are, first, prayer-texts; second, capitularies, that is, administrative regulations and/or admonitory texts issued by early Carolingian rulers; and third, letters. On this basis, I shall investigate the women religious to whom Alcuin wrote.

\section{The Abbess in the Prayer-text}

Here is an Oratio quando abbas vel abbatissa ordinatur (prayer when an abbot or an abbess is ordained), in an 8th-century Frankish Sacramentary: ${ }^{2}$

1 Barbara Yorke, Nunneries and the Anglo-Saxon Royal Houses (London, 2003), pp. 52, 161, 188.

2 Sacramentaire de Gellone, ed. A. Dumas, CCSL 159 (Turnhout, 1981), nos. 2578, 2579, pp. 399-401. Translation here courtesy of Carey Fleiner. The key words here are regimen animarum eligimus, electione, constituitur, digna, electa: like the abbot, the abbess is chosen and empowered to rule. 
Concede quaesumus omnipotens deus ut famulam tuam N. quem ad regimen animarum eligimus gratiae tuae dona prosequantur et ut te largiente cum ipsa nostra electione placeamus.

Omnipotens sempiterne deus divinum tuae benedictionis spiritum famulae tuae N. nobis propitiatus infunde ut quae per manus nostrae impositionem hodie abbatissae constituitur sanctificatione tua digna a te electa permaneat.

Grant it, we seek, omnipotent God, that your servant N., whom we have chosen for the guidance of souls (that they are endowed with the gifts of your grace), and that we greatly please you with this woman, our selection.

Almighty ever-eternal God, in our favour, fill your servant N. with the divine spirit of your blessing so that she, through the laying of our hands today, the woman, chosen by you, appointed to the [office of] abbess, will remain worthy, having been blessed by you.

Late in the 9th century, this was borrowed from the prayer following the anointing in the first, and thereafter much-copied, fully-fledged rite for the ordaining of a queen:

Omnipotens sempiterne Deus, divinam tuae benedictionis spiritum super hanc famulam tuam nostra oratione propitiatus infunde, ut quae per manus nostrae impositionem hodie regina instituitur, sanctificatione tua digna et electa permaneat... ${ }^{3}$

\section{Abbesses in Capitularies}

Seven extracts from capitularies issued by King Pippin and his son, King Charles (Charlemagne) present various approaches to the subject of abbesses. Pippin I, Council of Ver (11 July 755):

Domnus rex dicit quod vellit, ut, quando aliquas de ipse abbatissas ipse domnus rex ad se iusserit venire, semel in anno et per consensus episcopi

3 Ordo XIII (Erdmann Ordo), in Richard Jackson, ed., Ordines Coronationis Franciae. Texts and Ordines for the Coronation of Frankish and French Kings and Queens in the Middle Ages, 2 vols (Philadelphia PA, 1995-200o), 1:151. See further Janet L. Nelson, "Early Medieval Rites of Queen-making and the Shaping of Medieval Queenship," in Queens and Queenship in Medieval Europe, ed. Anne Duggan (Woodbridge, 1997), pp. 301-315 [repr. in Nelson, Rulers and Ruling Families in Early Medieval Europe (Aldershot, 1999), xv], at pp. 309-10, 314. 
in cuius parrochia est, ut tunc ad eum aliquas veniant, et sua iussione, si necessitas fuerit, et aliubi omnino debeat nec per villas nec per alia loca demorare, nisi tantum cum celerius potuerit ad ambulandum et ad revertendum. Et si iusserit rex venire, veniat.

The lord king says that it is his will that when the lord king himself orders any of those abbesses to come to him, once a year and with the consent of the bishop of the diocese they are in, they must come immediately, and on his command, if necessity arises, and must absolutely not stay at estates or other places, unless they can travel [to the king] and back more quickly that way. And if the king says, "Come!," she must come. ${ }^{4}$

Pippin, Council of Ver, chapter 2o:

[To the bishops], Illa monasteria ubi regulariter monachi vel monachas vixerunt, ut hoc quod eis de illas res demittebatis unde vivere potuissant, si regales erant, ad domnum regem fecissent rationes abba vel abbatissa.

About those monasteries where monks or nuns live in a Rule-based way [or, according to a Rule], that you [bishops] leave them with enough properties to live on, and if these were royal [monasteries], the abbot or abbess is to send in their accounts for them to the lord king. ${ }^{5}$

Charlemagne, Admonitio generalis, Aachen (23 March, 789):

Auditum est aliquas abbatissas contra morem sanctae Dei ecclesiae benedictionis cum manus impositione et signaculo sanctae crucis super capita virorum dare, necnon et velare virgines cum benedictione sacerdotali. Quod omnino vobis [episcopis et abbatibus], sanctissimi patres, in vestris parrochiis interdicendum esse scitote.

It has been heard that some abbesses, against the custom of the holy Church of God, give blessings on the heads of men with laying on of the hand and with the sign of the holy cross, and veil virgins with a priestly blessing. Know this, $\mathrm{O}$ you bishops and abbots, that this is totally forbidden in your dioceses. ${ }^{6}$

4 Pippin, Council of Ver, in Mg H Capitularia regum Francorum I, ed. A. Boretius (Hanover, 1883), no. 14, chapter 6, p. 34 .

5 Pippin, Council of Ver, MG H Capit. I, no. 14, chapter 20, p. 36.

6 Charlemagne, MG H Capit. I, no. 22, chapter 76, p. 60. 
Charlemagne, Capit. no. 33 (early 802):

Ut episcopi, abbates vel abbatissae quae ceteris prelati sunt, cum summa veneratione hac diligentia subiectis sibi preesse student, non potentiva dominatione vel tyrannide sibi subiectos premant.

That bishops, abbots and abbesses, who are in command of others, with the greatest veneration shall strive to command those subject to them with such diligence [that they] do not oppress those subject to them by dominating them by force or by tyranny. ${ }^{7}$

Charlemagne, Capit. no. 42 (Salz, 803/804):

Ut nullus ex clericale ordine, sacerdotes videlicet aut alii clerici, neque laicus, brunias aut arma infra monasteria puellarum commendare praesumat.

No-one of any clerical rank, that is, priests or other clerics, and no layman, must presume to store byrnies [mail shirts] or weapons inside convents of young women. ${ }^{8}$

Charlemagne, Capit. no. 73 (811), chapter 4, p. 165:

[Homines dicunt] quod episcopi et abbates sive comites dimittunt earum liberos homines ad casam in nomine ministerialium, similiter et abbatissae: hi sunt falconarii, venatores, telonarii, praepositi, decani et alii qui missos recipiunt et eorum sequentes.

Some men are saying that bishops and abbots and counts are leaving behind at home their free men under the name of officials, and abbesses are doing the same thing: [those left at home are termed] falconers, huntsmen, toll-takers, stewards, deans and others who receive [royal] missi and their retinues. ${ }^{9}$

Charlemagne, Capit. no. 74 (October, 811), chapter 10, p. 167:

Constitutum est, ut nullus episcopus aut abbas aut abbatissa vel quislibet rector aut custos aecclesiae bruniam vel gladium sine nostro permisso

7 Charlemagne, MGH Capit. I, no. 33, chapter 11, p. 93.

8 Charlemagne, MG H Capit. I, no. 42, chapter 8, p. 120.

9 Charlemagne, MGH Capit. I, no. 73 (811), chapter 4, p. 165. 
cuilibet homini extraneo aut dare aut venundare praesumat, nisi tantum vassallis suis.

It has been laid down that no bishop or abbot or abbess or any rector or guardian of a church shall presume without our permission to give or sell to any outsider [or foreign man] a byrnie or a sword, except only to their own vassals. ${ }^{10}$

These texts show abbesses in Francia being addressed in similar terms to those used for abbots, involved likewise in the service of the kingdom, including military service, running their institutions with similar types of agent, and accounting to the king for the management of their resources in similar ways. Abbesses were members of an institutional elite. Some abbesses were reported to be involved in scams very similar to those of abbots, that is, shirking or privatizing their public responsibilities. There were special problems too: some abbesses had violated the gender-bound rules governing the practice of holy rites and use of holy space: women were forbidden to bless men, or to lay consecrating hands on women. Finally, though abbesses shared with bishops and abbots liability to feel the lash of peremptory royal commands, those royal imperatives put abbesses peculiarly firmly in their place as lay-persons. "Read your capitularies!" (as Charlemagne commanded a count) has its counterpart in an abbess's being told, "If the king orders 'Come!', she is to come."

Women were deployed in the formation of early Anglo-Saxon kingdoms in what Barbara Yorke identified as "political needs ... and family strategies ... [and] royal nunneries [that] cannot be understood solely as religious institutions."11 Queens and abbesses were often associated in royal families, and "royal nunneries were often commanded by women who had once been queens." ${ }^{12}$ Similar needs and strategies are visible all over the post-Roman world. Just a century ago, Karl Voigt's pioneering study of Carolingian monastic policy included the connection between royal women and female monasticism..$^{13}$ The connection is clear in the list of Nomina reginarum et abbatissarum in the Durham Liber Vitae, an early medieval book used for commemorating the dead, and equally clear on the Continent. ${ }^{14}$ The great and royally-connected

10 Charlemagne, Mg H Capit. I, no. 74 (October, 811), chapter 10, p. 167.

11 Yorke, Nunneries, pp. 145-86, at 176.

12 Yorke, Nunneries, p. 174.

13 Karl Voigt, Die karolingischer Klosterpolitik (Stuttgart, 1917), pp. 163-204, 218-25.

14 Eva-Marie Butz and Alfons Zettler, "Commemoration and Oblivion. The Making of the Carolingian Libri Memoriales," in Memory and Commemoration in Medieval Culture, ed. Elma Brenner, Meredith Cohen, and Mary Franklin-Brown (Farnham, 2013), pp. 83-92. See also Dieter Geuenich, "A Survey of the Early Medieval Confraternity Books from the 
convent of Remiremont in the Vosges was founded in the early 7 th century, and its extant Liber Vitae was begun in $821 .{ }^{15}$ Seventeen names of abbesses were listed, commemorated as a category. Nunneries and the Anglo-Saxon Royal Houses provides evidence from multifarious sources of some fifty AngloSaxon abbesses for the period between the 7th to the 11th century, revealing remarkable changes across that time-span. It would be interesting to compare the statistics for abbesses in the Carolingian Empire.

\section{Letters}

In this paper I attempt nothing so ambitious. Rather, I look at a very small group of women who shared three characteristics: all received letters from $\mathrm{Al}$ cuin, sent in a quite limited period of time, between 786 and 804, and all were believed by the editor of those letters, the German scholar Ernst Dümmler (1830-1902), to have been certainly or probably abbesses. To begin with Alcuin (c.735-804): he spent most of his long life at York, the centre of Northumbrian royal and ecclesiastical power. He was a secular cleric at the minster, never holding a rank higher than that of a deacon. During the 780 os and early 790 , he oscillated between England and the Continent, retaining strong personal interests in York after his move-permanent as it turned out - to Francia, in 794, when Charlemagne invited him to stay at his court. Some two years later, at the king's behest, Alcuin moved to St Martin's, Tours, where he remained based until his death in 804. He was not an abbot, but a lay-abbot, hence, by canonical standards, his post was anomalous. Charlemagne himself gave Alcuin a tongue-lashing on this subject in the course of a famous dispute between $\mathrm{Al}$ cuin and Theodulf. ${ }^{16}$ His letters to kings and aristocrats were often microversions of the Specula principum (mirrors of princes) genre which were to diffuse the ideas and practices of Christian culture widely in the Carolingian world. ${ }^{17}$ Though the time he spent as a teacher at Charlemagne's court was

Continent," in The Durham Liber Vitae and its Context, ed. David Rollason, A.J. Piper, Margaret Harvey, and Lynda Rollason (Woodbridge, 2004), pp. 141-47, at p. 145.

15 Liber Memorialis von Remiremont, ed. E. Hlawitschka, Karl Schmid and Gerd Tellenbach, MGH Libri Memoriales I (Dublin and Zurich, 1970), fol. 35v.

16 Ep. 247, in MGH Epistolae Karolini aevi II, ed. E. Dümmler (Berlin, 1895), Charlemagne to Alcuin, pp. 399-401. For lay-abbots, see Franz Felten, Äbte und Laienäbte im Frankenreich (Stuttgart, 1980).

17 Hans Hubert Anton, Fürstenspiegel und Herrscherethos in der Karolingerzeit (Bonn, 1968), pp. 85-131, remains the classic account; see now also Joanna Story, Carolingian Connections. Anglo-Saxon England and Carolingian Francia, c. 750-870 (Aldershot, 2003), passim 
quite brief, his influence was deep, and, thanks to his students in the next generation, lasting. The oscillations explain the chronology of Alcuin's some 280 surviving letters: hardly any from the York years, but thereafter some sent from England to Francia, some in the other direction, but most to Continental recipients. Which letters survived, and where, depended largely on selections of the manuscript material made either at York in Northumbria on the instructions of Alcuin himself, or at Salzburg in Bavaria by Alcuin's friend Bishop Arn of Salzburg. ${ }^{18}$

Alcuin's letters thought by Dümmler to have been addressed to abbesses were the following, which I have set out in alphabetical order, with numbers of letters sent to each recipient in square brackets:

Adaula ?abbess in diocese of Salzburg, Ep. 68 (c.789-796)

Æthelburh, daughter of Offa, abbess, Epp. 36 (c.793-795);

102 and 103 (796, after 18 April); and 300 (797-804)

Æthelthyrth, abbess, widowed mother of Æthelred of Northumbria

(+796), Epp. 79 (793-796); 105 and 106 (post-18 April 796)

Gisela, abbess of Chelles, Epp. 15 (793), 32 (793×95), 84 (793-96),

154 (793, September), 164, (early 799), 195 (80o, before 19 April),

213 (early 801), 214 (early 801), 216 (801, after 4 April), 228 (801)

Gundrada,?nun ceteris in palatio virginibus exemplar, Epp.?

204 (800? mid-June), 241 (c.801), ?279 (804), 309 (801-4)

Hundruda ?nun in palatio regis [Offae], Ep. $62(c .786-796)$

Regnoida, ?abbess, Ep. 297 (796-804)

Two of the recipients are otherwise unknown. The first, Adaula, was addressed by Alcuin as soror. In a very short letter, Alcuin urged her to virtue, but there is

but esp. pp. 4-10, 61-64, 93-109, 135-44, 181-84. For Alcuin at court, see Mary Garrison, "The Emergence of Latin Literature and the Court of Charlemagne," in Carolingian Culture: Emulation and Innovation, ed. Rosamond McKitterick (Cambridge, 1994), pp. 111-40; Garrison, "The Social World of Alcuin. Nicknames at York and the Carolingian Court," in Alcuin of York. Scholar at the Carolingian Court, ed. L.A.J.R. Houwen and Alasdair A. McDonald, Mediaevalia Groningana 22 (Groningen, 1998), pp. 59-79, and Donald A. Bullough, "Alcuin's Cultural Influence: the Evidence of the Manuscripts," in Alcuin, ed. Houwen and McDonald, pp. 1-26.

18 Donald A. Bullough, Alcuin: Achievement and Reputation (Leiden, 2004), p. 36; Maximilian Diesenburger and Herwig Wolfram, "Arn und Alkuin 790 bis 804: zwei Freunde und ihre Schriften," in Erzbischof Arn von Salzburg, ed. Meta Niederkorn-Bruck and Anton Scharer (Vienna and Munich, 2004), pp. 81-106. 
no hint that she was an abbess. ${ }^{19}$ She may or may not be identified with the Atula (named without any title of office) listed in the Liber Confraternitatum of St Peter's, Salzburg. ${ }^{20}$ Alcuin's contact with her may well have come through his friend Arn of Salzburg. The second is Regnoida, whom Alcuin addressed, again in a short letter, as "most beloved mother in Christ," and whom he asked to pray for him..$^{21}$ Too little is known of either of them or their contexts to indicate whether either was an abbess, or went by some other title.

More interesting, and interestingly similar to one another, though documented by different authors, are Hundruda in Mercia and Gundrada in Francia. Alcuin addressed Hundruda as a Deo devota femina, a "woman devoted to God."22 He praised her piety, her life of sobriety and chastity and "the examples you set in speaking modestly about the truth and in acting in the honourable state of chastity towards both younger and older people so that all may be edified, [and] so that the devotion of a rule-based life [regularis vitae] at the king's palace [in palatio regis] becomes visible in the way you behave [conversatio]."23 From Alcuin's pen-portrait, which is all that is known of her, Dümmler flatly inferred: "ergo Hundruda monacha fuit" - "so Hundruda was a nun."24 This was not the only possible inference, however. A pious aristocratic and well-connected woman living in a busy environment that included both the young and the old of both sexes, as well as the queen, and the king's son, was teaching informally at the Mercian court rather than occupying any institutionalized role.

Only two of the four letters which Dümmler thought Alcuin might have written to Gundrada were clearly addressed to her. One of the two letters whose addressee has been doubted, but I think was indeed Gundrada, was called by Alcuin filia in Christo carissima. Alcuin wrote of the well-known $f a$ miliaritas between himself and his spiritual daughter, "desiring that your

19 Alcuin, Ep. 68, p. 112; the lemma (extra note) in this 11th-century manuscript has: Epistola Albini magistri ad Ulam abbatissam.

20 MGH Necrologia Germaniae II: Diocesis Salisburgensis, ed. S. Herberg-Fränkel (Berlin, 1904), p. 14.

21 Ep. 297, p. 456, whom Alcuin also addressed as "most holy mother and most sweet handmaid of God": the lemma simply says "ad Renoide."

22 Ep. 62, p. 105.

23 Ep. 62 (c.789-796), pp. 105-06.

24 Dümmler, MGH Epp. II, p. 105, n. 4: "ergo Hundruda monacha fuit." See the riposte of Sarah Foot, Veiled Women, 1: The Disappearance of Nuns from Anglo-Saxon England (Aldershot, 2000), p. 57; also Janet L. Nelson, "Gendering Courts in the Early Medieval West," in Gender in the Early Medieval World. East and West, 300-9oo, ed. Julia M.H. Smith and Leslie Brubaker (Cambridge, 2004), pp. 185-98, at p. 190, and Janet L. Nelson, "Was Charlemagne's Court a Courtly Society?" in Court Culture in the Early Middle Ages, ed. C. Cubitt (Turnhout, 2003), pp. 39-57, at p. 46. 
nobleness [nobilitas] may gleam brightly in your behaviour [mores] and may your power [potestas] shine in the sweetness of your piety, and your eminence [sublimitas] may be loved and your authority [dignitas] be praised .... Every friendship [amicitia] which is accustomed to be kept between human beings [homines] is null and void if it is without trust [fides]."25 Alcuin's vocabulary in this letter implied that the woman for whom it was intended was of exceptionally high rank, and he combined this tellingly with his own sense of "the trustworthiness of our faith [in each other] [fiducia fidei nostrae]." It was as if any gender-gap had been overwhelmed by Gundrada's superior moral, and distinctively royal, qualities. One other small piece of evidence to support that interpretation comes from a charter of Charlemagne's dated 9 May 813. The forms and formalities of Charlemagne's charters sometimes included the name-in tironian notes, or Carolingian shorthand - of the powerful personage who had intervened to secure the charter's issue. Charlemagne's very last extant charter was requested by "Gundradus" (that was how the editor Engelbert Mühlbacher read it). But it could equally well be "Gundrada," for, given the difficulties of deciphering tironian notes, the last syllable may be a feminine one. ${ }^{26}$ If that's the right reading, then the influential requester was not an ambasciator (a male requester) but an ambasciatrix (a female one)—Gundrada. ${ }^{27}$ From that intervention, it could be inferred that Gundrada's rank enabled her to exercise a kind of political influence otherwise available only to men. This would tally with the impression given by the vocabulary deployed by Alcuin in Ep. 204.

Paschasius Radbert, more commonly known as Radbert of Corbie, had been nurtured at the convent of Notre Dame, Soissons, where the abbess in the early 9th century was Theodrada, Charlemagne's cousin. Radbert identified Gundrada, her sister Theodrada and brothers Wala and Bernar, and their considerably older half-sibling Adalard of Corbie, as members of the regalis prosapia, the royal line, offspring of Bernard, bastard son of Charles Martel. ${ }^{28}$ In his Life of Adalard, Radbert offered a pen-portrait of Gundrada which resembled Hundruda's at Offa's Mercian palace, and during more or less the same years. This was no coincidence. Carolingian connections produced similar contexts for such women to flower in as models of piety. Radbert produced his own penportrait of Gundrada: "[she was] a virgin more close to the king [and] the most noble woman of noble ones [virgo familiarior, nobilium nobilissima] ... she was

\footnotetext{
25 Ep. 204, pp. 337-38.

26 My thanks go to David Ganz and Martin Hellmann for sharing their wondrous expertise.

27 Nelson, "Gendering courts," p. 191.

28 Paschasius Radbert, Vita Adalardi chapter 7, MGH Scriptores in Folio 2, ed. G.H. Pertz (Hannover, 1829), p. 525 .
} 
unique in having remained a virgin amidst the lustful heats of the palace." ${ }^{29}$ In a letter datable to "c. 801," Alcuin addressed Gundrada as sponsa Deo dignissi$m a$ ("bride most worthy for God"). Alcuin's nickname for her, Eulalia (after the virgin-martyr of Merida), signalled membership of the inner circle of those bound by familiaritas to each other and (in this context) to Charlemagne/ David. Alcuin was so confident in Gundrada's influence with Charlemagne that he asked her to transmit his apologies for having had to refuse a summons to court: "speak to my lord David so that he's not angry with his servant." Alcuin urged Gundrada to continue to be "an exemplar for all the other virgins [ $c e$ terae virgines] in the palace, so that they may learn from your holy behaviour how to guard themselves, or, if they should fall, how to rise again," and "may they be as noble in their conduct as they are by parentage." ${ }^{30}$ Alcuin's third letter was addressed to "a sister and a daughter in Christ," putatively identified by Dümmler in a note as "Gundrada and Theodrada." ${ }^{11}$ The fourth letter, addressed to his "dearest sister in Christ's love, Eulalia," was among the very last of Alcuin's letters to survive: Gundrada had asked for an explanation of "the reason of the soul," and Alcuin responded with a lengthy exposition in 14 capitula ending with a 67 -line poem. ${ }^{32}$ Palace life apparently offered space for a little cohort of virtuous noblewomen, and Gundrada apparently led one, but there is no evidence that it was a convent rather than an informal discussiongroup. Both Hundruda and Gundrada lived in but were not entirely of a court milieu. Each was a teacher, though not necessarily only of other women, but it seems that in both cases, their chief responsibilities, morally and spiritually, were for women (not necessarily a large group of them), living devoutly as in a Rule-based life (regularis vitae). There is no clear evidence, however, that Hundrada and Gundrada were abbesses. ${ }^{33}$

29 Paschasius Radbert, Vita Adalhardi, chapter 33, p. 527.

30 "Esto ceteris in palatio virginibus totius bonitatis exemplar, ut ex tua discant sancta conversatione se ipsas custodire vel cadentes resurgere," Ep. 241, pp. 386-87.

31 Ep. 279, pp. 435-36, where Dümmler seems to identify Theodrada as Gundrada's considerably younger sister. For debate about Theodrada's marital status, see Johannes Fried, "Elite und Ideologie oder Die Nachfolgeordnung Karls des Großen vom Jahre 813," in La royauté et les élites dans l'Europe carolingienne (du début du Xe siècle aux environs de 920), ed. Régine Le Jan (Lille, 1998), pp. 71-109, at pp. 90-95; Karl Ubl, Die Konstruktion eines Verbrechens (Berlin and New York, 2008), p. 379; Martina Hartmann, Die Königin im frühen Mittelalter (Stuttgart, 2009), p. 105.

32 Ep. 309, pp. 473-78 (omitting chapters 2-12). The lemma, or short note in the manuscript, says "Incipit liber de anima ad Gundradane," expressed in other manuscripts as "De animae ratione liber ad Eulaliam virginem."

33 F. Felten, Vita religiosa sanctimonialium: Norm und Praxis des weiblichen religiösen Lebens vom 6. Bis zum 13. Jahrhundert (Korb, 2011). 
The best-known of the women considered so far is Gisela. Most scholars, until recently, identified her as an abbess — and her convent as Chelles. ${ }^{34}$ She is exceptionally well-documented, as Charlemagne's sister and a member of the royal family, as a court figure, and as the person who commissioned or patronized the Annales Mettenses Priores, one of the key annalistic sources of the reign of Charlemagne. No contemporary writer of annals, charters or letters identified her as an abbess. In none of the ten letters she received from Alcuin was she identified as an abbess within the letter itself. In the one surviving letter that Gisela (along with her niece Rotrud) wrote to Alcuin, she did not identify herself as an abbess: she and Rotrud called themselves humillimae Christi famulae, Gisela et Rodtruda. ${ }^{35}$ Why then have modern historians so firmly assigned Gisela the title and office of abbess? The answer turns out to be simple: Dümmler provided Gisela with that title in no fewer than four of the lettersummaries he put before the edited text of the letters. Alcuin, by contrast, in the letters themselves, addressed Gisela as virgo nobilis (Ep. 15), Gisela and Rotrud as mater et filia Christi (Ep. 32), and Gisela again as dilectissima in Christi soror (Ep. 84), as carissima in Christi soror (Ep. 154), as karissima in Christo (Ep. 164). ${ }^{36}$ In the next five letters, none of which was tagged with an explanatory note, the address-forms were similar to those in the preceding five, i.e. the woman (or women) was/were addressed in the familiar terms of spiritual kinship, most often of sisterhood in Christ. In four of the last five letters to Gisela or to Gisela and Rotrud (Epp. 195, 214, 216 and 228), Dümmler in each of his brief letter-summaries identified Gisela as abbatissa Calensis, abbess of Chelles, and he did the same for Gisela's one letter to Alcuin, Ep. 196. The supposition that Gisela was an abbess (and the most important in the empire) had been made much earlier in the 17th century, by Jean Mabillon and by Gottfried Wilhelm Leibniz; Dümmler had either borrowed it or re-supposed it. These identifications constitute the only 'evidence' there is for Gisela having been abbess of Chelles, or indeed an abbess at all. Martina Hartmann must take the credit for being the first scholar in the 21st century to point this out, in 2007, somewhat en passant (for her topic in the relevant paper was "concubine or queen?"). ${ }^{37}$ If Gisela had been abbess of Chelles, it would have been bizarre

34 Yorke, Nunneries, p. 54; Anne-Marie Helvétius, "Pour une biographie de Gisèle," in Splendor Reginae. Passions, genre et famille. Mélanges en l'honneur de Régine Le Jan, ed. Laurent Jégou et al. (Turnhout, 2015), pp. 161-68.

35 Ep. 196 (800, after 19 April), pp. 323-25.

36 Several of these have an extra note (lemma) added by the scribe, but not in the addressformula at the beginning of the letter.

37 Martina Hartmann, "Concubina vel regina? Zu einigen Ehefrauen und Konkubinen der karolingischen Könige," Deutsches Archiv 63 (2007), 545-67. 
indeed if the strictly contemporary author of the Annales Mettenses Priores, writing at Chelles, had not mentioned it. Gisela, it must be concluded, was not an abbess.

The remaining two religious women to whom Alcuin wrote were both Anglo-Saxon royals. Alcuin addressed neither of them as abbess. Dümmler in his brief summary-title to Ep. 36, named Æthelburh, daughter of King Offa, as abbess of Fladbury, Worcestershire, but the identification of Fladbury is certainly wrong, and scholars have not identifed any alternative convent. ${ }^{38}$ Æthelthryth, whom Dümmler named in his summary-title to Ep. 79 as an abbess, but without naming a convent, had been queen of Northumbria and wife of King Æthelwald Moll (d.765), and mother of King Æthelred (d.796), but there is no evidence as to which convent, if any, she presided over. These conclusions, at first blush disappointingly negative, reveal on closer investigation something of the relationships between Alcuin and each of these two women. They also permit comparison with the tone and terms in which Alcuin addressed at least one of his Frankish correspondents. Before making the case for the interest and importance of these two letters to these two Anglo-Saxon women, it is worth recalling, very briefly, four characteristics of early medieval letters in general. First, the writer presents himself or herself as in direct communication with the recipient: as Alcuin put it, "the letter speaks in place of the voice." ${ }^{39}$ Second, what look, at first, like very personal and private letters are at the same time highly rhetorical, often meant to be read out to a public. Third, they use a limited range of words and themes repeatedly and in formulaic ways (we still do, but the themes and tone are different): munera, munuscula (gifts, gifties); amicitia (friendship); caritas (love); dilectio (love); memoria (memory, commemoration); elimosina (alms). Fourth, the writer typically situates himself or herself as inferior to the recipient: parvitas mea (my smallness), but sometimes opts for a more equal, familiar level: vestra familiaritas. Alcuin, though born of a relatively insignificant family, had, by his latter years, acquired the moral authority to teach virtue to high-born women, expecting, in return, that such women were in a position to intercede for him with the ruler, just as he himself could intercede with the ruler on those women's behalf. By his latter years too, though often far from court, Alcuin understood very well

38 Yorke, Nunneries, p. 66, n. 49 .

39 Ep. 102. See also Giles Constable, Letters and Letter-Collections (Turnhout, 1976); Garrison, "The Emergence of Latin Literature at the Court of Charlemagne," and "The English and the Irish at the Court of Charlemagne," in Karl der Grosse und sein Nachwirken, ed. Paul Leo Butzer et al (Turnhout, 1997), pp. 97-124; Donald Bullough, Carolingian Renewal (Manchester, 1991), and Alcuin: Achievement and Reputation. 
that Anglo-Saxon courts were places where powerful women lived and worked-and networked.

Alcuin addressed two letters to Æthelthryth, mother of the Northumbrian king Æthelred. She had withdrawn to a nunnery (place unknown) after her husband's death in 765 or not long after. ${ }^{40}$ Dümmler dated Ep. 79 to $793-6$, and Ep. 105 to 796, post 18 April—the date of the murder of King Æthelred. That Alcuin's letters to Æthelthryth were written so long after she was widowed could imply a longstanding bond, perhaps continuous from the 760 and $770 \mathrm{~s}$. It was only after her son's regaining of the kingdom of Northumbria in 790, however, that Alcuin's interest in communicating with Æthelthryth became stronger: she was now a force to be reckoned with in Northumbrian politics. His return to York between 790 and 793 was not coincidental, then, and nor was the writing of Ep. 79 after his return to Francia. Addressing Æthelthryth as "sister in Christ and mother," Alcuin began as usual with thanks for gifts and appreciation of caritas, followed by a reminder of the special responsibilities of those in command of others (qui praesunt aliis) and who thus "carried the care of many and must answer for them all on the day of judgement." Alcuin demanded his "dearest sister" to remember that those thus subjected must be taught by example:

Do not keep silent through any fear of man! ... Honour old women and old men as mothers and fathers, love the youthful as brothers and sisters, and teach the little ones like sons and daughters. Labour in the work of God ... with alms and gifts. ... Make your way of life [conversatio] an example to others of all goodness, so that the high honour of your personal position is praised by all, loved by many and the name of God glorified in you...

This letter reads, curiously, as if Æthelthryth were a proxy for her son, for whom he wrote the sharply critical Epp. 16 and 18 after the Scandinavian attack on Lindisfarne on 8 June 793 . In writing to the king's mother, Alcuin was continuing an old association in new and problematic circumstances, writing with his private situation in mind. Other letters written in $795^{-96}$ show that Alcuin was thinking, again, about returning to York, and also that he considered himself a likely candidate to replace Archbishop Eanbald (I) who had been in post

40 Barbara Yorke, "Æthelbald, Offa and the Patronage of Nunneries," in Ethelbald and Offa: Two Eighth-Century Kings of Mercia, ed. David Hill and Margaret Worthington, BAR British Ser. 383 (Oxford, 2005), pp. 43-48. 
since $780 .{ }^{41}$ Æthelthryth and Alcuin shared the shock of King Æthelred's murder on 18 April 796.42 Alcuin wrote to Æthelthryth as his "most beloved mother in Christ": the terms of spiritual kinship allowed Alcuin to represent Christ as Æthelthryth's spiritual son, and her grief for her carnal son to be transmuted into gladness that "his soul lives in Christ." Alcuin included a practical note: "Meanwhile you still have control of your own property, so use it to give almsyou never know what tomorrow might bring!" Alcuin asked Æthelthryth, "most beloved mother, to consider me now, though unworthy, as your spiritual son in place of your carnal one." 43 Knowing that carnal son as they both did, Alcuin and Æthelthryth may have found some consolation in irony. Less than four months later, Archbishop Eanbald died and was immediately succeeded by Eanbald II, whom scholars generally assume was a kinsman (perhaps a nephew?) of Eanbald I. To him, Alcuin now wrote in apparently conventional congratulatory terms but with a pen steeped in vitriol. ${ }^{44}$ It is not clear whether the news reached Francia before or after Alcuin was given and accepted the layabbacy of St Martin at Tours. For Alcuin, in any case, the option of return to York and high ecclesiastical office had gone for good.

Finally, Æthelburh, daughter of Offa, and sister-in-law of King Æthelbert of Northumbria, appeared as an abbess (convent unknown) in 792. She received four letters from Alcuin (Epp. 36, c.793-95; 102 and 103, 796, after 18 April; 300, 797-804). The sequence of the first three of these letters parallels that of Alcuin's letters to Æthelthryth. Again the timing of the first falls within Alcuin's three years back at York. Remaking bonds with Mercian as well as Northumbrian royals was high on Alcuin's agenda. Ep. 36's praise of fertile virginity is boilerplate: "a few days' labour is remunerated by eternal rewards, and the heavenly bridegroom rejoices in the generous scale of alms." But here Æthelburh was addressed as "Eugenia," and with Alcuin, every nickname told a story: here the name appeared in an apocryphal martyr-tale set in the mid-3rd century, and briefly recorded in the 9th-century Old English Martyrology. ${ }^{45}$ The story as elaborated later, portrayed Eugenia, daughter of a Roman governor: she escaped paternal control, dressed as a man, got herself baptized, and became an abbot. Later her sex was discovered, she moved to Rome where she was martyred. It is to be hoped that Alcuin explained to Æthelburh how the

\footnotetext{
41 Epp. 42, 43, 44, 46, 47, 48.

42 Ep. 105.

43 Ep. 106.

44 Ep. 114, cf. Epp. 115, 116, and the more amicable 226.

45 Christine Rauer, ed., The Old English Martyrology (Cambridge, 2013), pp. 36-37.
} 
name should be interpreted. Names were important to Alcuin and his contemporaries (and some of those same names still are significant: apparently Eugenia has recently become an icon of the LGBTQ community). Alcuin brought Offa's daughter Æthelburh, into a charmed circle: of the purest and highest-born women with connections to the Carolingian court.

In Ep. 102, Alcuin did not address Æthelburh as Eugenia, but simply as in Deo dilectissima filia. He reflected that though letters from a distance were inferior to a good chat (invida terrarum longinquitas mutuae confabulationis prohibet dulcedinem), they could continue a conversation; “... I won't be asking you for anything new in letters that I've not already said to you face-to-face." Did Alcuin sense a certain fragility in Æthelburh's commitment, and now renewed his efforts to firm it up? The letter's tone then changed completely with the phrase "Ecce me modo infidelitas patriae in tantum horret ut reverti timeo"- "Look, the current state of disloyalty/treachery in our country appalls me so much that I am frightened to return, and I know of nothing I can do about this except weep and think about the lamentations of Jeremiah." This was as good as a declaration that he would never return. Amidst the general ruin, Alcuin wept hot tears over the fate of Æthelburh's widowed sister. "The woman deprived of the bed of her husband must be encouraged to serve Christ in the convent." Alcuin asked Æthelburh to remember his name in her prayers.

In the final section, he shifted into a quite different mode:

Liudgardam quoque nobilem feminam, quae tibi munusculi loco pallium direxit, habeto in Dei dilectione ut sororem; illiusque nomen cum nominibus sororum tuarum per ecclesiasticas cartas scribere iube. Honorabilis tibi est amicitia illius, et utilis. Misi dilectioni tuae ampullam et patenam ad offerendam in eis domino Deo tuis manibus oblationem.

And have the noble woman Liudgard, who sent you a shawl [?or veil] as a giftie, as a sister in the love of God. For you this friendship is honourableand useful. And order her name to be inscribed along with the names of your sisters (i.e. nuns) in the lists of [your] church.

Liudgard was Charlemagne's fifth and last wife, and well-known to Alcuin. He may well have suggested to her that she send the shawl, for which the Scots giftie seems an apposite translation, as a token of spiritual sisterhood with Offa's daughter. Political and religious honour and utility were entwined here. Along with her sister, Æthelburh too was now endangered. Alcuin ended with his own gifts: he sent a jug and a plate for Æthelburh personally to offer the 
oblations in the Mass, and to pray for him while doing so. The role of lay people in bringing oblations to the altar here acquired overtones. ${ }^{46}$ Did Æthelburh, as a nun, have special qualifications for liturgical performance, with the convent church an appropriate stage? Or did she receive the title and role of abbess while her father was still alive? ${ }^{47}$ In Ep. 103 Alcuin thanked his "sweetest sister" for the munuscula caritatis tuae, her prayers, and her familiaritas. He commended to her caritas the bearer of his letter, asking her to seek the widowed queen's patronage in ensuring the man's safe return in patriam (Francia), and to greet the queen in his name, assuring her that "we have always been faithful to her, ... especially now, when she outlives her husband the most excellent king." Finally in Ep. 300, Alcuin, thanking Æthelburh for letters and munera, responded to yet another turn of fortune's wheel. Offa was dead, and in both Northumbria and Mercia there were new kings whom Alcuin castigated as "tyranni non rectores; nec ut olim reges a regendo sed a rapiendo dicuntur""tyrants, not rectors, and not called 'kings' because they rule but because they plunder." This was a letter of consolation, but also of strong support: tribulations are a sign of the trial of the just: "Gold shines only when tempered in fire. It won't be easy for the devil to lay waste the house which is the habitation of Christ." Æthelburh had planned to go to Rome, it seems, but at the time of receiving Alcuin's letter had not yet succeeded. She should now give the money collected for the journey to the poor instead, and trust in God to provide for another attempt. In this letter Æthelburh was once again addressed as Eugenia.

Those then are the letters. They belong in contexts: where prayer-texts show Frankish abbesses exercising a kind of rule (regimen) but in a house kept apart-a house, as Alcuin said in which Christ resides, and where capitularies show that at least some Frankish abbesses, high-born and hugely wellresourced, were expected to participate along with abbots and bishops and secular officers in the activities of the state and service to the ruler. The letters reflect convent living and public service rather faintly, but they bring to life, in small Anglo-Saxon kingdoms as well as in the big Frankish one, sets of social relationships structured on an economy and language of gift-exchange and an ethic of generous alms-giving. The letters show hubs of communication with and even in royal courts inhabited by women as well as men. Just occasionally, and probably part-time, a high-born and learned woman could come to

46 David Ganz, "Giving to God in the Mass: The Experience of the Offertory," in The Languages of Gift, ed. Wendy Davies and Paul Fouracre (Cambridge, 2010), pp. 18-32. 
exercise a teacherly hegemony in the palace. Between Alcuin, the deacon of no more than a middle-ranking family, and women who were royal and always resourceful, a kind of friendship could blossom which sometimes came close to parity. The nicknames he chose for some of his correspondents reveal Alcuin as a man of passionate sociability. His letters, like so many lightningflashes, suddenly illuminate a social world of caritas, of amicitia and familiaritas, of gifts and giftieness.

In the end, religious women are-and were-hard to pin down. The varied terms for their roles and ranks indicate a fluidity that did not apply to those of male religious. ${ }^{48}$ Perhaps these ways baffled people at the time. Where was the dividing-line between a Deo devota and an abbess? Why did so many abbesses retain a life-interest in the properties of their convents? In what sense did the nuns of Abbess Emhild's community at Milz in Thuringia share with her pariter in handing over the convent to Fulda? ${ }^{49}$ And did Emhild feel it necessary to insist that she was not giving Milz to the relics in the altar and its endowment because her male cousins claimed shares in those relics and that church and its property, but because "my tradition to God and St Mary is made to the relics of St. Mary that are my own ... in my reliquary"? 50 The words of Susan Wood are salient here: "At one level, that of religious life," abbess or abbot renounced their property when being professed, but if that property belonged to her or his own foundation, "at another level, that of private law," she or he remained that property's proprietor "until it was explicitly given away. ... Consciousness of one level may creep into the other and contribute towards ambiguities as to whether past, present or post obitum donations are intended," adding a comment on "the haziness of civil personality" in early medieval times. ${ }^{51}$ It seems appropriate to end this paper by returning, via Susan Wood's comments just quoted, to some words of Barbara Yorke, apropos the taking of religious vows: "How such actions were actually perceived by early medieval individuals is one

48 Franz J. Felten, Vita religiosa sanctimonialium (collected papers, all relevant to the early medieval period), see n. 33 above.

49 E.E. Stengel, ed., Urkundenbuch des Klosters Fulda, 2 vols. (Marburg, 1913-58), 1.2, no. 264, "cum ea [Emhild] pariter communibus manibus traditionem fecerunt." See Matthew Innes, State and Society in the Early Middle Ages (Cambridge, 200o), pp. 26 ("the redoubtable Emhild"), 125.

5o Stengel, ed., Urkundenbuch des Klosters Fulda, 1.2, no. 154. See Susan Wood, The Proprietary Church (Oxford, 2006), pp. 126-27, 136.

$5^{1}$ Wood, Proprietary Church, pp. 126-27, and see also pp. 136, 182, 316-17. 
of the most difficult things for a modern historian to discover. ... In a period when the rights of the individual are often seen as paramount, it is easy to forget that even in relatively recent times people readily accepted that 'duty' should have priority over personal preferences and so constructed their selfworth from the correct performance of it." ${ }^{52}$

Yorke, Nunneries, p. 10. 